\title{
Impact of Kaolin on Physicomechanical Properties of Density-graded Cement Bonded Paperboards
}

\begin{abstract}
Aina K. Sesan,* Olayiwola Y. Bolarinwa, and Oriire L. Temitope
Paperboards of thickness $0.6 \mathrm{~cm}$ with densities of $0.8,0.9$, and $1.0 \mathrm{~g} / \mathrm{cm}^{3}$ were produced from waste papers mixed with cement and kaolin. Printing and corrugated waste papers were employed in the proportions of 50.0/25.0/25.0, 50.0/37.5/12.5, and 50.0/12.5/37.5 (paper/cement/kaolin), respectively. The dimensional and strength properties of the boards were investigated. The values obtained range from 0.40 to $0.94 \mathrm{~g} / \mathrm{cm}^{3}, 51.19$ to $68.10 \%, 0.14$ to $3.10 \%, 0.01$ to 1.69 $\mathrm{Nmm}^{-2}$, and 119.98 to $567.32 \mathrm{Nmm}^{-2}$ for observing the density, water absorption, thickness swelling, modulus of rupture, and modulus of elasticity, respectively. The board of proportion 25/25 of kaolin/cement was densest with high strength. As the nominal density and kaolin content were increased from 12.5 to $37.5 \%$, an increase was observed in density and strength properties. Similarly, as the proportion of kaolin and cement content were increased, the rate of moisture uptake to cavity decreased. This study shows that boards from printing papers were more dimensionally stable than corrugated papers. It revealed that printing papers could be better raw material for manufacture paperboard than corrugated papers. Information provided in this study could be used as a guideline for the manufacture of paperboard reinforced with kaolin as an additional constituent for quality improvement.
\end{abstract}

Keywords: Paperboards; Corrugated; Papers; Cement; Kaolin

Contact information: Department of Forest Product Development and Utilization, Forestry Research Institute of Nigeria, P. m. b. 5054, Forest hill, Jericho, Ibadan, Nigeria;

* Corresponding author: sesan2003toy@gmail.com

\section{INTRODUCTION}

Sourcing of wood and pulp materials for panel products production begins with felling of trees. Approximately 4 billion trees worldwide are lost annually to this process, comprising 35\% of all harvested trees (EGN 2011). The major environmental impacts of felling are deforestation, drought, and desertification. Deforestation alone comprises $25 \%$ of annual world carbon emissions, and the determinants are reported by Ezeudu et al. (2019). The incessant cuttings of trees has been the most common forest activity causing environmental problems such as hurricane damage, soil erosion, and desertification. This action has caused adverse effects such as global warming, melting of polar ice, sea level rise, climate change, extinction of plant and animal species, disruption of forests' natural processes of carbon bio sequestration and destruction of forest land for agriculture (Ezeudu et al. 2019). For many years, wood has being a major raw material for the manufacture of wood panel products. The wood-based industry seems increasingly dependent on particles and pulp made from logs (Xing et al. 2006). There is growing effort to replace wood with more eco-friendly and sustainable raw materials such as recyclable paper, non-wood fiber materials, and agro-residues. 
Some researchers have taken the initiative of using other materials as an alternative for manufacturing of composites (Çolak et al. 2007; Wang et al. 2007; Ashori and Nourbakhsh 2009). This positive initiative is currently aiming to solve the ecological damage caused by felling of trees in forests. The key players in pulp and wood businesses have moved commendably forward to harmonize their production with reforestation, afforestation, and sustainable forestry (Ezeudu et al. 2019). It has been noted that over 300 million tons of papers are used globally in a year and it has been reported that global consumption of paper has grown by 400 percent in the last 40 years (EGN 2011).

Nigeria is Africa's largest wood producer and a major exporter of timber resources. In the year $2000,781,200 \mathrm{~m}^{3}$ of industrial round wood valued at 36.10 million US dollars were exported to Europe from Africa (FAO 2004). However, today in the nation's forest industry, the paper sub-sector is the worst performing sector among all the industries (Aina and Adeniyi 2019). Three paper mills were established by the federal government of Nigeria in the 1970s, Nigerian Paper mill in Jebba, Nigeria Newsprint Manufacturing Company in Oku Iboku, and Iwopin Pulp and Paper Company in Ogun State. These industries started well but could not sustain operation and stopped operations in 1996 (Udohitinah and Oluwadare 2011; Azeeze et al. 2016). Even after these industries were privatized in 2006, they still could not perform (Ogunwusi and Onwualu 2013). The effect of non-performance of these industries was rightly reflected in importation of paper and paperboard, which was worth 658.1 billion naira between the years 2010 and 2015. These import trade sums are even higher than pharmaceutical products, beverages, spirits, and vinegar data added together. The net amount for papers imported increased to 798.9 billion naira of aggregate values for printed books, newspaper, pictures, and other miscellaneous paper products. About $\$ 66$ million worth of paper and paperboard material were imported into Nigeria from India alone in 2017 (Ezeudu et al. 2019).

However, as demand for paper and paperboard has been increasing, so also have there been increases in paper waste found in municipal solid waste (EPA 1994). These wastes are the largest single component of material generated. About 25 to $40 \%$ of the municipal solid waste generate each year consists of paper and paper products. In 1993, about 71 million ton of paper and paperboard were reportedly generated in municipal solid waste, representing $38 \%$ of all municipal solid waste generated in the United States (EPA 1994). There is a tendency that as population growth and economic development increase, the volume of paper and paperboard waste generated annually in many countries also increases. Paper and paperboard waste are also the most heavily recovered and recycled component of municipal solid waste, accounting for $59 \%$ of all waste generated (EPA 1994). The accumulated paper waste found in all countries of the world can cause certain serious environmental problems (Prasad et al. 2015). The largest proportion of paper waste is reused by the paper industry, and according to the present state of technology, there will always be a certain percentage of waste paper meant for economic and technical reasons. A suitable option for recyclable waste paper is to be use it for composites. First, the waste paper constitutes a largely unutilized resource, and secondly the costs of processing waste papers will make the cost of composites much lower than the composites made from wood or fiber particles (Grigoriou 2003; Ashori and Nourbakhsh 2009). The use of environmentally friendly, low cost, and lightweight materials for manufacture of composites in building industries prompted the investigation of how waste papers can be incorporated into production of cement bonded particleboard that could be of benefit to the environment and also attain structural standards. 
Another big challenge is the incessant increase in the price of cement, which is a known factor in the manufacture of particleboard, which is becoming expensive. It has become urgent to start investigating any possible binder that could be environmentally friendly. Clay displays favorable physical and chemical properties for an industrial material and could be a cheap, healthy, and available alternative to cement (Malu et al. 2013). In Nigeria, deposits of kaolin (clay) are widely distributed in many regions with differ properties that might probably due to geological differences (Kefas et al., 2007). The geological differences also determine the physical and technological properties such as binding ability, shrinkage and plasticity (Nwoye 2003). Therefore, this study investigated the suitability of papers, clay and cement for the production of density graded paperboards and their utilization properties (strength and dimensional properties).

\section{MATERIALS AND METHODS}

\section{Preparation of Materials}

Papers, kaolin, and cement were employed for the production of paperboards in this study. Printing papers and corrugated paper boxes were used. The printing papers were collected at computer and printing vendors located inside the University of Ibadan, Oyo State, Nigeria. The corrugated boxes were collected from different retailer shops in Bodija market, Ibadan, Nigeria. Both papers were shredded and soaked separately in a drum of water at $100{ }^{\circ} \mathrm{C}$ for $48 \mathrm{~h}$ to defragment them (de-pulp). The soaked papers were milled into wet slurry pulps, the excess water was drained to reduce viscosity, and the mashed paper was oven dried to attain $12 \%$ moisture content. A $50 \mathrm{~kg}$ bag of cement made by Lafarge Company at Ewekoro in Ogun State, Nigeria was purchased from the retailer depot along Dugbe road at Ibadan, Nigeria. Additionally, soil known as kaolin was collected from the Forestry Research Institute of Nigeria (FRIN) at Ibadan, Oyo State, Nigeria. The soil was thoroughly milled into powder and sieved with a wire mesh of size $1.00 \mathrm{~mm}$ to obtain fine powder of equal homogenous size with the cement.

\section{Board formation}

The paperboards were produced after appropriate quantities of paper, cement, and kaolin were thoroughly hand-mixed according to mixing proportions of 50/25/25, $50 / 37.5 / 12.5$, and 50/12.5/37.5 (paper/cement/kaolin) weight to weight basis and of densities $0.8 \mathrm{~g} / \mathrm{cm}^{3}, 0.9 \mathrm{~g} / \mathrm{cm}^{3}$, and $1.0 \mathrm{~g} / \mathrm{cm}^{3}$, respectively. The mixture of these particles in each proportion for each density was thoroughly hand mixed, uniformly spread on a flat wooden caul plate and a wooden mould of size $35 \mathrm{~cm} \times 35 \mathrm{~cm}$ was used as a guide. Four steel bolts of thickness $0.6 \mathrm{~cm}$ were placed at the four corners of the mould as stoppers to achieve the desired thickness. The mixed particles were hand pre-pressed and further pressed to final thickness of $0.6 \mathrm{~cm}$ using a hydraulic presser (L-0489; Lucas Engineering Company, Lagos, Nigeria) of force $1.75 \mathrm{~N} / \mathrm{mm}^{2}$. The boards were stacked and firmly held together under the hydraulic cold presser for period of 24 hours to solidify before de-mould. De-moulded boards were stacked in the laboratory to dehumidify to prevent fracture or crack. The board samples were later air-dried in an open space for 7 days to cure, trimmed to avoid edge defects and then cut into specific sample sizes of $15.4 \mathrm{~cm} \times 15.4 \mathrm{~cm}$ and $17.8 \mathrm{~cm} \times 5.1 \mathrm{~cm}$ for determination of physical and mechanical properties in accordance of ASTM D1037 (1999). 


\section{Determination of Properties}

The board density was calculated in accordance of Badejo (1999) by dividing the mass of the test sample with the volume. The test sample of size $17.8 \mathrm{~cm} \times 5.1 \mathrm{~cm}$ was subjected to three-point-flex measurements for the determination of modulus of rupture and modulus of elasticity. The test was carried out using a universal testing machine of model WDW-50 (Jinan Hensgrand Instrument Co., Ltd., Jinan, China) with moveable crosshead speed of $5 \mathrm{~mm} / \mathrm{min}$. A square of dimensional size $15.4 \mathrm{~cm} \times 15.4 \mathrm{~cm}$ for each test sample was immersed in water at room temperature of $26 \pm 2{ }^{\circ} \mathrm{C}$ for $24 \mathrm{~h}$ to determine its behavior to moisture resistance. The weight and thickness of the sample were measured before and after immersion, and the values collected were used to calculate water absorption and thickness swelling. Furthermore, $2 \mathrm{~g}$ of kaolin soil sample was analyzed using an ultraviolet (UV) visible spectrophotometer of model T60 (PG instruments Ltd., Leicestershire, England). Flame photometer of model PFP 7 (Senway Ltd., Cambridge, England) and atomic absorption spectrophotometer of model 210VGP (Buck Model-Bulk Scientific, East Norwalk, USA) was used to determine the exchangeable bases, micronutrient, organic carbon, organic matter, total nitrogen and available potassium. Finally $10 \mathrm{~g}$ of kaolin was tested on $\mathrm{pH}$ meter to determine the $\mathrm{pH}$ values of the soil.

\section{Experimental Design}

The data obtained were analyzed through $2 \times 3 \times 3$ factorial experiments in a completely randomized design to determine the level of significance among these factors (paper type, mixing proportion, and density). The software for statistical package for social sciences (SPSS) version 20.0 (IBM SPSS Statistics Inc) was used for the data analysis and all separations of treatment means were done using Duncan multiple range test (DMRT) at the 5\% level of probability.

\section{RESULTS AND DISCUSION}

\section{Physical Properties}

The mean values of observed density, water absorption (WA), and thickness swelling (TS) for the kaolin-cement paperboards are presented in Table 1. The values obtained ranged from 0.46 to $0.96 \mathrm{~g} / \mathrm{cm}^{3}, 46.20$ to $68.10 \%$, and 0.14 to $2.78 \%$ for density, WA, and TS, respectively. These values agree with reported findings (Perry 2011; Nwankwojike et al. 2014; Malu et al. 2018). The values obtained for boards made from printing paper ranged from 0.56 to $0.94 \mathrm{~g} / \mathrm{cm}^{3}, 46.20$ to $68.10 \%$, and 0.15 to $0.25 \%$. The values of corrugated papers ranged from 0.46 to $0.69 \mathrm{~g} / \mathrm{cm}^{3}, 52.44$ to $66.92 \%$, and 1.14 to $3.10 \%$ for density, WA, and TS, respectively. The dimensional values obtained in this study were higher but still within the same range of values obtained by Fuwape and Oyagade (1993), who used cement with particles of wood at different ratios. However, the values reported in this study differed from the values obtained in a previous study when cement was used as a binder to produce particleboards (Zhou and Kamdem 2002). Comparing the dimensional values obtained in this study with the dimensional standard required by ISO (2005), it was determined that the TS values must be $<2 \%$. As shown in Fig. 1, the paperboards of equal proportion of cement to kaolin $(25 / 25)$ had the highest 
density with lowest swelling of printing papers, but results were different in boards made of corrugated papers.

Table 1. DMRT Conducted on the Mean Values Obtained for Paperboards

\begin{tabular}{|c|c|c|c|c|c|c|}
\hline Production Variables & Levels & \multicolumn{3}{|c|}{ Physical Properties } & \multicolumn{2}{|c|}{$\begin{array}{c}\text { Mechanical } \\
\text { Properties } \\
\left(\mathrm{N} / \mathrm{mm}^{2}\right)\end{array}$} \\
\cline { 3 - 7 } & & $\begin{array}{c}\text { Density } \\
\text { Observed } \\
\left(\mathrm{g} / \mathrm{cm}^{3}\right)\end{array}$ & WA (\%) & TS (\%) & $\begin{array}{c}\text { Modulus } \\
\text { of } \\
\text { Elasticity }\end{array}$ & $\begin{array}{c}\text { Modulus } \\
\text { of } \\
\text { Rupture }\end{array}$ \\
\hline \multirow{2}{*}{ Type of paper } & Printing & $0.75^{\mathrm{a}}$ & $58.80^{\mathrm{a}}$ & $0.18^{\mathrm{a}}$ & $372.99^{\mathrm{a}}$ & $1.23^{\mathrm{a}}$ \\
\cline { 2 - 7 } & Corrugated & $0.57^{\mathrm{b}}$ & $61.18^{\mathrm{b}}$ & $2.40^{\mathrm{b}}$ & $322.16^{\mathrm{b}}$ & $1.05^{\mathrm{b}}$ \\
\hline Density (g/cm $)^{*}$ & 0.8 & $0.61^{\mathrm{c}}$ & $63.02^{\mathrm{c}}$ & $1.38^{\mathrm{b}}$ & $256.67^{\mathrm{c}}$ & $0.87^{\mathrm{c}}$ \\
\cline { 2 - 7 } & 0.9 & $0.66^{\mathrm{b}}$ & $60.38^{\mathrm{b}}$ & $1.40^{\mathrm{b}}$ & $340.61^{\mathrm{b}}$ & $1.14^{\mathrm{b}}$ \\
\cline { 2 - 7 } & 1.0 & $0.72^{\mathrm{a}}$ & $56.56^{\mathrm{a}}$ & $1.08^{\mathrm{a}}$ & $445.51^{\mathrm{a}}$ & $1.42^{\mathrm{a}}$ \\
\hline \multirow{2}{*}{$\begin{array}{c}\text { Mixing ratio* } \\
\text { (kaolin/cement/paper) }\end{array}$} & $25 / 25 / 50$ & $0.68^{\mathrm{b}}$ & $58.54^{\mathrm{a}}$ & $1.66^{\mathrm{c}}$ & $339.04^{\mathrm{b}}$ & $0.90^{\mathrm{c}}$ \\
\cline { 2 - 7 } & $12.5 / 37.5 / 50$ & $0.61^{\mathrm{c}}$ & $62.57^{\mathrm{b}}$ & $1.49^{\mathrm{b}}$ & $271.36^{\mathrm{c}}$ & $1.22^{\mathrm{b}}$ \\
\cline { 2 - 7 } & $37.5 / 12.5 / 50$ & $0.69^{\mathrm{a}}$ & $58.85^{\mathrm{a}}$ & $1.01^{\mathrm{a}}$ & $432.39^{\mathrm{a}}$ & $1.31^{\mathrm{a}}$ \\
\hline
\end{tabular}

${ }^{*}$ Represents significance at $5 \%$ level of probability, while superscript letter represents difference between each factor

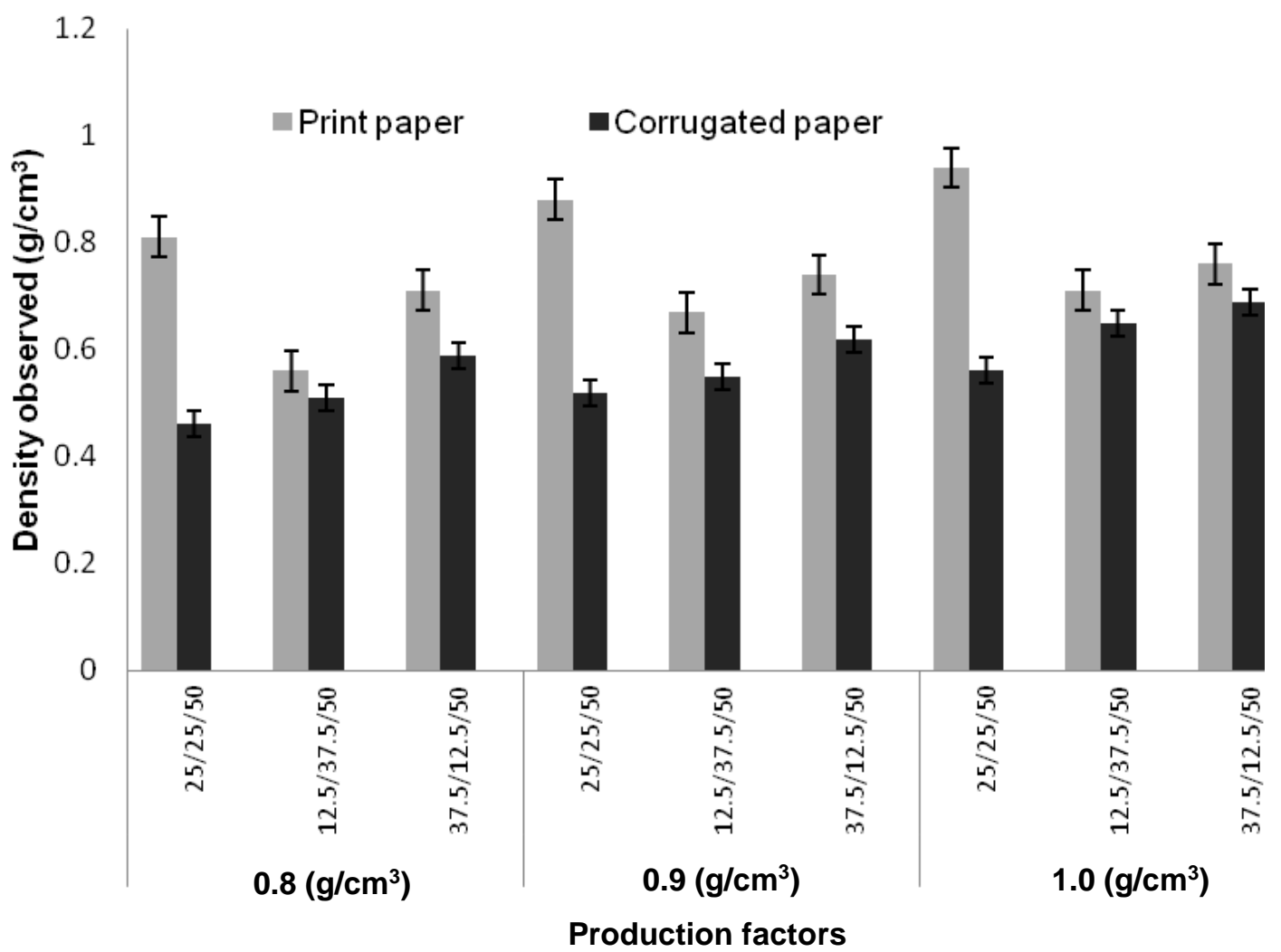

Fig. 1. Effect of production variables (kaolin/cement/paper and density) on observed density 
The values obtained for density observed in this study were attributed to the density displayed by the materials used. Both cement and kaolin are dense, with densities ranging from 1.32 to $2.70 \mathrm{~g} / \mathrm{cm}^{3}$ and 2.90 to $3.06 \mathrm{~g} / \mathrm{cm}^{3}$. Mixture of these two materials with fibers from lighter weight paper gave better dimensional values because the pulps were perfectly covered with the cement and kaolin. As the kaolin content was decreased with cement in proportion of $12.5 / 37.5$, the density of paperboard also increased for corrugated paper, while the density of paperboard from printing waste paper decreased. In contrast, as kaolin content was increased to the proportion of $37.5 / 12.5$, the density of paperboard also decreased for printing waste paper but it increased when compared with (12.5/37.5/50.0), while the density of paperboard from corrugated waste paper increased. This observation implies that the impact of cement as binder is active and strong. Cement still plays a major role as binding reagent between the paper and kaolin, but additions of kaolin also improve internal bonding of the boards.

It is known that cement has high compressive strength of $19.5 \mathrm{~N} / \mathrm{mm}^{2}$ and gives high compatibility result through pressing which may yield good plasticity boards; kaolin also has low shrink-swell capacity (Nwankwojike et al. 2014). The properties displayed by cement and kaolin altered the inter-particles bonding relationship in paperboards. Cement and kaolin fill the pores in the matrix, which thereby reduce the permeability of the board (i.e., water absorption). However, as the proportion of cement was increased, more internal spaces in pores were filled, which reduced moisture permeability. The variations that occurred between the printing and corrugated paperboards for TS and WA in Figs. 2 and 3 could be attributed to the presence of lignin in corrugated paper. The amorphous regions within the cellulose structure and lignin both have affinity to moisture and tend to get swollen by water (Nishiyama et al. 2003). As noted, water found in pulp fiber is analogous to hydrated forms of minerals and the degradation caused by hydrate formed molecular mass of cellulose chains within the pulp fiber that correlate with the dimensional and strength properties of paperboards (Annergren 1996; Maloney et al. 1998). 


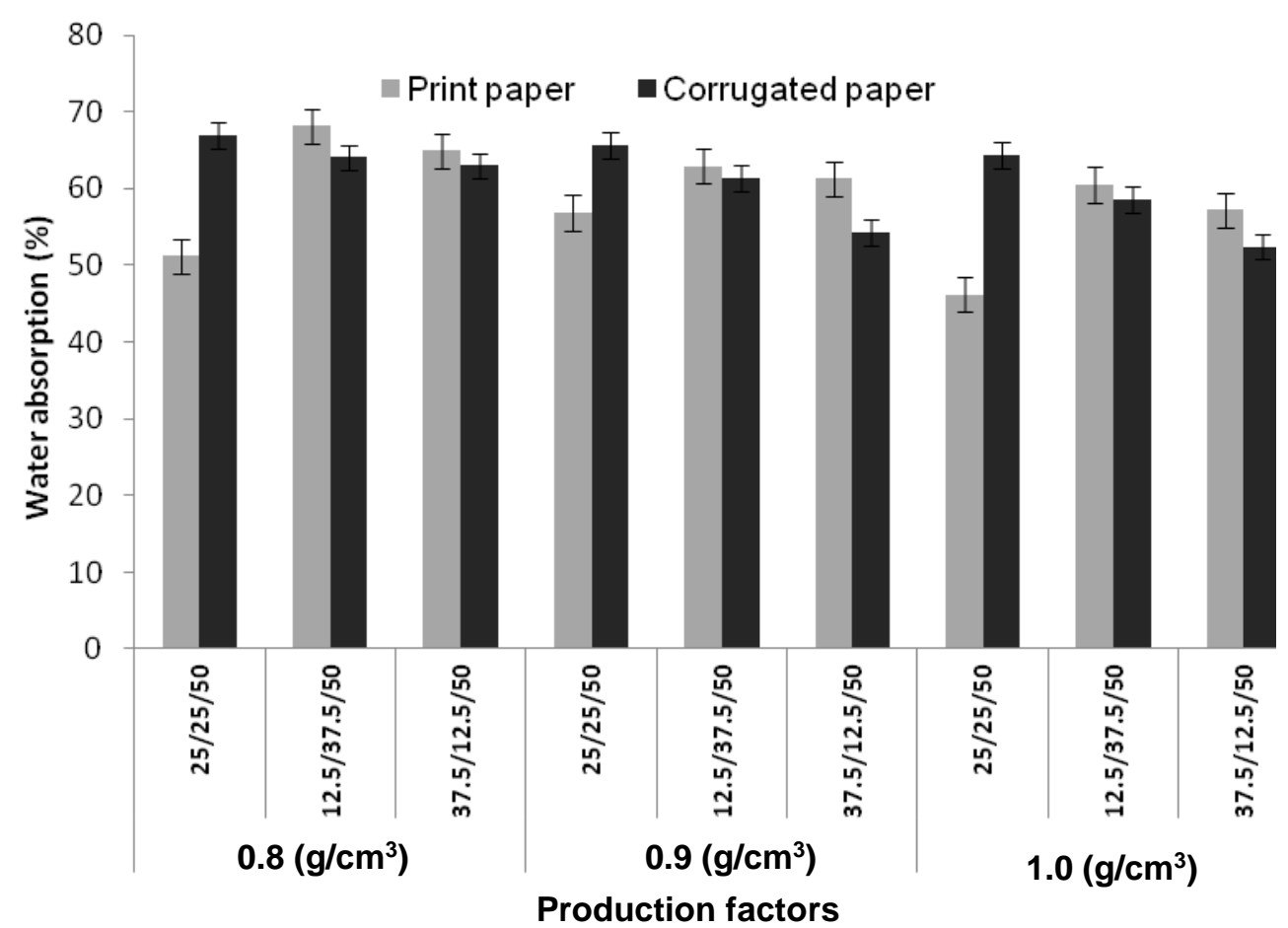

Fig. 2. Effect of production variable (clay/cement/paper and density) on water absorption

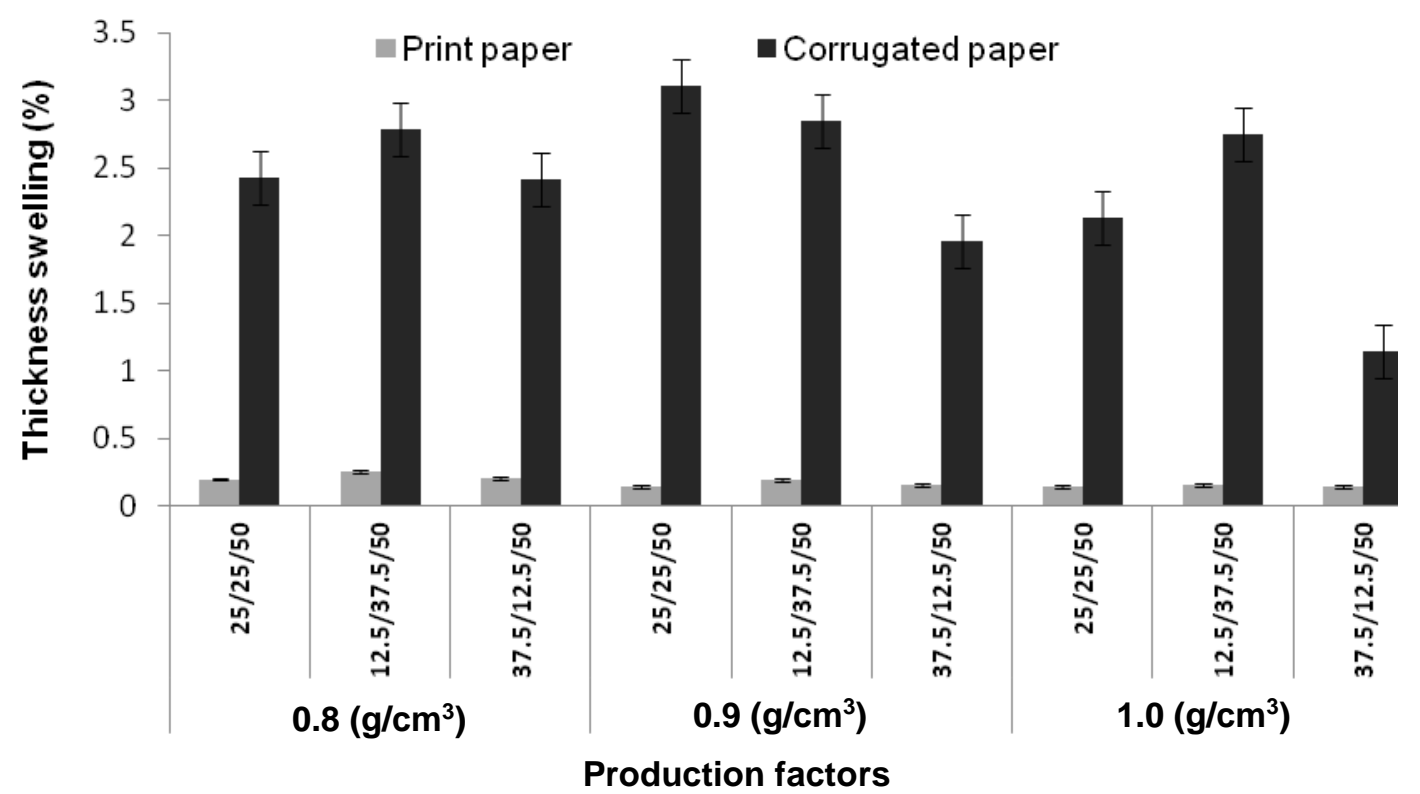

Fig. 3. Effect of production variable (clay/cement/paper and density) on thickness swelling

The differences in dimensional behavior of printing and corrugated paper could be attributed to the strong oxidizing agent used for manufacture of printed documents in paper making. Bleaching occurs through chlorination using chlorine dioxide or ozone followed by alkaline extraction that removes more anionic charged groups than they generate, thereby leaving the fiber in a less charged, less swollen and less bondable conditions (Laine 1997; Laine and Stenius 1997). The paper formed through these 
reactions was used for paperboard in this study. The addition of cement and kaolin might have aided bonding ability for the printing paper. As presented in Table 1, all factors considered in the production of paperboards were significant at the 5\% level of probability for density, TS and WA respectively. Paperboards made of printing paper at $1.0 \mathrm{~g} / \mathrm{cm}^{3}$ and mixing proportion of 37.5/12.5 (cement $/$ kaolin) were denser and has better dimensional stability than the others. The values obtained for WA and TS in this study decreased as the density increased, but the values obtained for physical properties fell within the range of values previously reported (Bejó et al. 2005, Del Menezzi et al. 2007).

\section{Strength Properties}

The values obtained for modulus of elasticity and modulus of rupture of paperboards are illustrated in Figs. 4 and 5, and the mean values for each factor are presented in Table 1. The values obtained for modulus of elasticity and modulus of rupture of the paperboards made from printing and corrugated papers ranged from 190.2 to $567.3 \mathrm{~N} / \mathrm{mm}^{2}$ and 0.55 to $2.13 \mathrm{~N} / \mathrm{mm}^{2}$ for printing papers and also ranged from 120.0 to $472.3 \mathrm{~N} / \mathrm{mm}^{2}$ and 0.55 to $1.49 \mathrm{~N} / \mathrm{mm}^{2}$ for corrugated papers. Paperboards made from printing paper of an equal proportion of cement and kaolin of 25/25 had the highest modulus of elasticity value, which gradually decreased as the proportion of kaolin to cement decreased by 37.5/12.5. As the proportion of kaolin to cement increased by 12.5/37.5 the MOE values also increased. The bulkiness of the materials used in this study might have contributed to stress transfer/concentration reactions in boards. It was shown that paperboard made from denser materials have higher density. The density of the materials corresponds to the strength properties of the products (Izekor 2013). Furthermore, the chemical composition of each material (kaolin, cement, and paper) may influence the strength properties of the paperboards made from printing and corrugated paper.

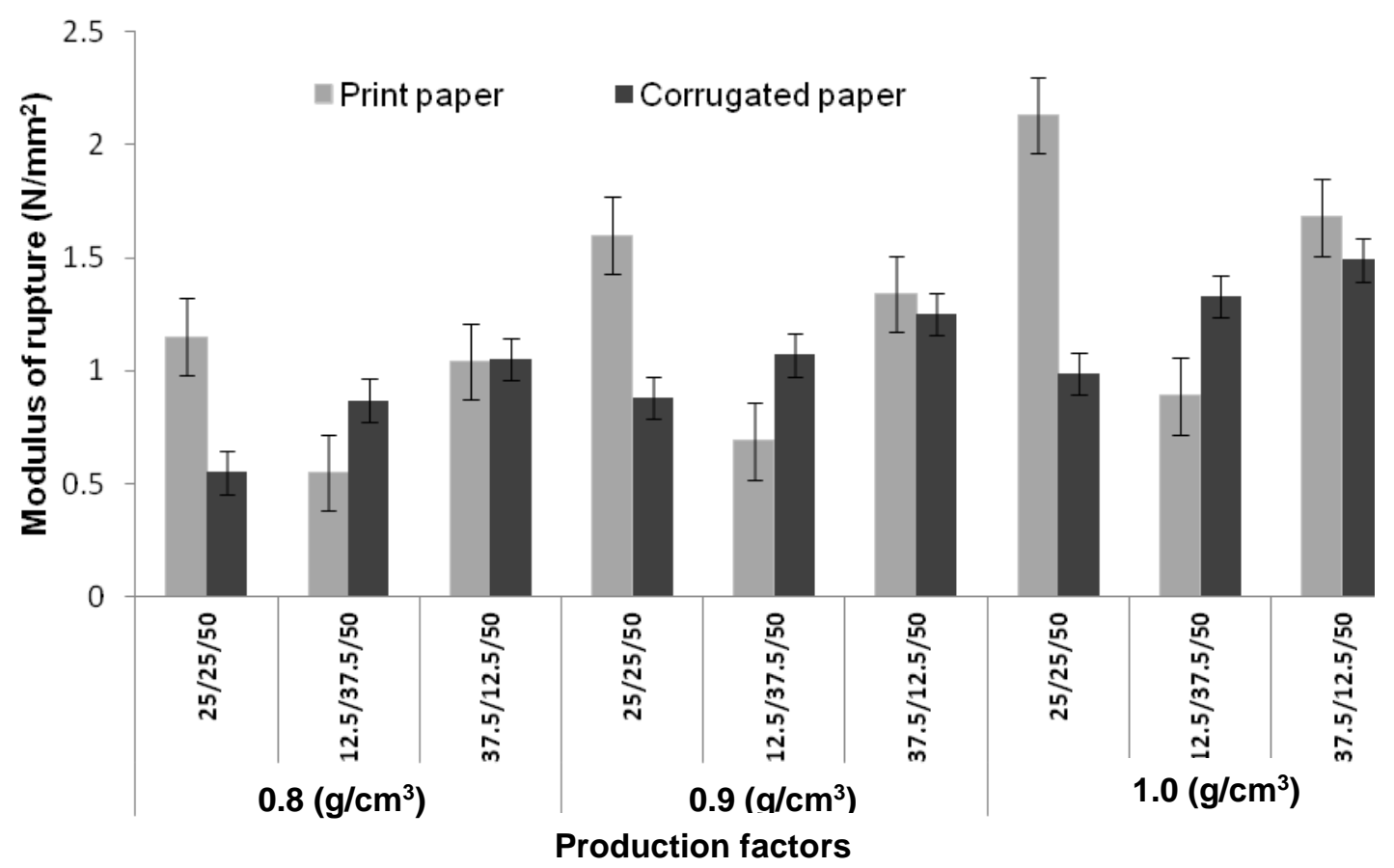

Fig. 4. Effect of production variable (clay/cement/paper and density) on modulus of rupture 


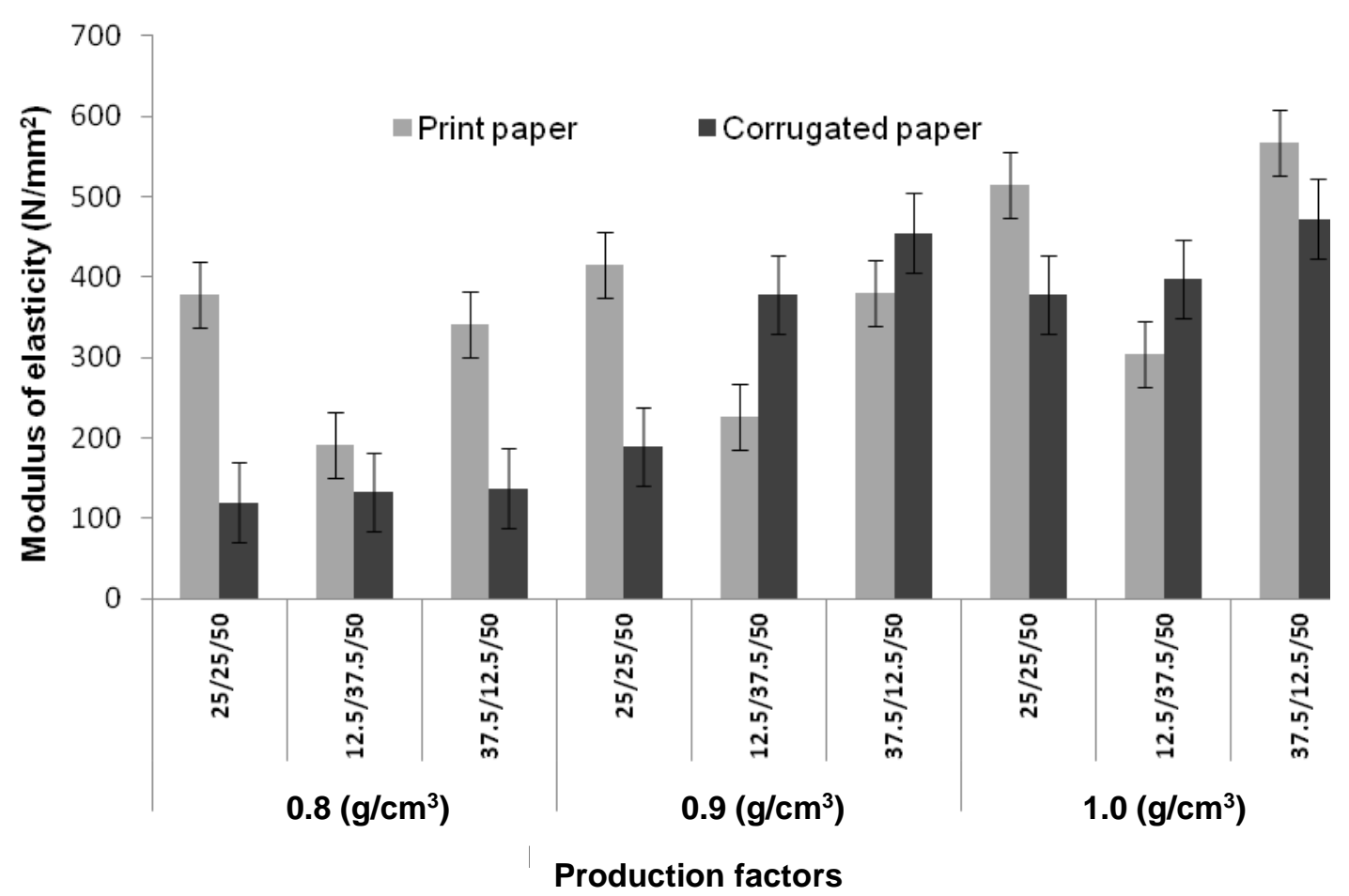

Fig. 5. Effect of production variable (clay/cement/paper and density) on modulus of elasticity

As presented in Table 2, kaolin has a high proportion of exchangeable bases, namely $\mathrm{Na}, \mathrm{K}$, and $\mathrm{Mg}$. When reacted with $\mathrm{H}_{2} \mathrm{O}$, it produces alkali oxide, which is responsible for plasticity (Nnuka and Enejor 2001; Bergaya et al. 2006). Furthermore, the presence of mineral oxides, such as $\mathrm{Fe}_{2} \mathrm{O}_{3}, \mathrm{MgO}, \mathrm{CaO}$, and $\mathrm{Na}_{2} \mathrm{O}$ in kaolin are responsible for its application in structural items like bricks, floor tiles, and paper (Kefas et al. 2007). The composition for kaolin is dominated by silica and alumina, which is often used for manufacture of floor tiles (Nwajuagu and Aneke 2001; Bergaya et al. 2006). Kaolin has a high percentage of silica that makes it a potential raw material for brick production. The increase in strength properties witnessed in this study can be attributed to the compaction ratio between the cement, kaolin, and paper. Kaolin has been known to aid stress dispersion with fiber and inter granular position with fibre promote firmer bond cement and paper. Kaolin has good plasticity and it has mullite and glossy bond that improve strength properties (Kefas et al. 2007).

Table 2. Chemical Values for Kaolin Soil Used for the Production of Paperboards

\begin{tabular}{|c|c|c|c|c|c|c|c|c|c|c|c|c|c|}
\hline \multicolumn{2}{|c|}{ Properties } & & & & & \multicolumn{3}{c|}{$\begin{array}{c}\text { Exchangeable Bases } \\
\text { (cmol/kg }\end{array}$} & \multicolumn{3}{c|}{$\begin{array}{c}\text { Micronutrient } \\
\text { (mg/kg) }\end{array}$} \\
\hline Soil & $\begin{array}{c}\mathrm{pH} \\
\left(\mathrm{H}_{2} \mathrm{O}\right)\end{array}$ & $\begin{array}{c}\text { O.C. } \\
(\%)\end{array}$ & $\begin{array}{c}\text { O.M. } \\
(\%)\end{array}$ & $\begin{array}{c}\text { T.N. } \\
(\%)\end{array}$ & $\begin{array}{c}\text { Avail. } \\
\text { P. } \\
(\mathrm{mg} / \mathrm{kg})\end{array}$ & $\mathrm{Na}$ & $\mathrm{K}$ & $\mathrm{Ca}$ & $\mathrm{Mg}$ & $\mathrm{Mn}$ & $\mathrm{Fe}$ & $\mathrm{Cu}$ & $\mathrm{Zn}$ \\
\hline Red & 4.16 & 2.23 & 3.38 & 0.54 & 34.6 & 1.38 & 0.17 & 3.7 & 12.9 & 34 & 6.8 & 3.1 & 188 \\
\hline
\end{tabular}

O.C. represents Organic Carbon; O.M. represents Organic Matter; and T.N. represents Total Nitrogen

The outcome of the result of analysis of variance carried out at 5\% level of probability to test the level of significance for MOE and MOR are presented in Table 1. 
All factors considered for the production of paperboard in this study for MOE and MOR tests were significantly different at the $5 \%$ level of probability. As presented in Table 1, paperboard made from printing paper had higher MOE and MOR values than the corrugated paper. With respect to density, boards made from $1.0 \mathrm{~g} / \mathrm{cm}^{3}$ had the highest values for MOE and MOR. With regards to mixing ratio, board made from proportion of 37.5/12.5 kaolin to cement had the highest values MOE and MOR.

\section{CONCLUSIONS}

1. The production of density graded paperboards made from printing and corrugated waste papers was carried out successfully.

2. It was also revealed that the production variables of density, mixing proportion, and paper types contributed to the properties of the composites.

3. The study revealed that fiberboards made from printing paper had better strength than the boards made from corrugated waste papers. The board of density $1.0 \mathrm{~g} / \mathrm{cm}^{3}$ had the best strength properties with low dimensional values.

4. Similarly, the proportion of kaolin to cement also has significant effects on physical and strength properties of the boards.

5. The best paperboard was made from printing paper at cement to kaolin proportion of $25 / 25$ at $1.0 \mathrm{~g} / \mathrm{cm}^{3}$. It was denser, stiffer, stronger, and more dimensionally stable than others.

\section{ACKNOWLEDGEMENTS}

The authors gratefully acknowledge the support and assistance provided by the Forestry Research Institute of Nigeria, Ibadan, Nigeria

\section{REFERENCES CITED}

Aina, K. S., and Adeniyi I. M (2019). "Revamping pulp and paper industries for employment opportunities in Nigeria," Proceedings of the $41^{\text {st }}$ Annual Conference of Forestry Association of Nigeria, Abuja, Nigeria, pp. 635-643.

Annergren, G. E. (1996). "Strength properties and characteristics of bleached chemical and mechanical pulps," in: Pulp Bleaching, Principles and Practice, Dence C. and Reeve D (eds.), TAPPI Press, Atlanta, GA, USA, pp. 717-747.

Ashori, A., and Nourbakhsh, A. (2009). "Characteristics of wood plastic composites made of recycled materials," Waste Management 29(4), 1291-1295. DOI: 10.1016/j.wasman.2008.09.012

ASTM D1037 (1999). "Standard test method for evaluating properties of wood-base fiber and particle panel materials," ASTM International, West Conshohocken, PA, USA.

Azeeze, M. A., Andrew, J. E. and Sithole, B. B. (2016). "A preliminary investigation of Nigerian Gmelina arborea and Bambusa vulgaris for pulp and paper production," 
Maderas. Ciencia y Tecnología 18(1), 1-17. DOI: 10.4067/S0718221X2016005000007

Bejó, L., Takáts, P., and Vass, N. (2005). "Development of cement bonded composite beams," Acta Silvatica et Lignaria Hungarica 1, 111-119.

Bergaya, F., Theng, B. K. G., and Lagaly, G. (2006). "Handbook of clay cement bonded particleboard using CCA-treated wood removed from service (Composites and Manufactured Products)," Forest Products Journal 52(3), 77-81.

Çolak, S., Çolakoğlu G., Aydin I., and Kalaycioğlu H. (2007). "Effects of steaming process on some properties of eucalyptus particleboard bonded with UF and MUF adhesives," Building and Environment 42(1), 304-309.

Del Menezzi, C. H. S, de Castro, V. G., and de Souza, M. R. (2007). "Production and properties of a medium density wood-cement boards produced with oriented strands and silica fume," Maderas. Ciencia y Tecnología 9(2), 105-115.

EGN (2011). "Ecology Global Network," (http://www.ecology.com/2011/09/10/paperchase), Accessed on 19/07/19.

Ezeudu, O. B, Agunwamba, J. C., Ezeasor, I. C., and Madu, C. N. (2019). "Sustainable production and consumption of paper and paper products in Nigeria: A review," Resources 8(1), 53. DOI: 10.3390/resources 8010053

FAO (2004). "Trends and current status of the contribution of the forestry sector to national economics," (http://www.fao.org/3/ad493e/ad493e00.htm), Accessed on 12 November 2018.

Fuwape, J. A., and Oyagade, A. O. (1993). "Bending strength and dimensional stability of tropical wood-cement particleboard," Bioresource Technology 44(1), 77-79. DOI: 10.1016/0960-8524(93)90212-T

Grigoriou, A. H. (2003). "Waste paper-wood composites bonded with isocyanate," Wood Science \& Technology 37, 79-90.

ISO (2005). "Pulps preparation of laboratory sheets for physical testing Part 1: Conventional sheet form method," International Standardization for Organization, Geneva, Switzerland.

Izekor, D. N. (2013). Anatomical and Strength Characteristics of Teak (Tectona grandis L.F) Grown in Edo State, Ph.D. Dissertation, Department of Forestry and Wood Technology, Federal University of Technology Akure, Nigeria.

Kefas, H. M., Patrick, D. O., and Chiroma, T. M. (2007). "Characterization of MayoBelwa clay," Leonardo Electronic, Journal of Practices \& Technologies 6(11), 123 130.

Laine, J. (1997). "Effect of ECF and TCF bleaching on the charge properties of kraft pulp," Paperi Ja Puu-Paper and Timber 79(8), 551-559.

Laine, J., and Stenius, P. (1997). "Effect of charge on the fibre and paper properties of bleached industrial kraft pulps," Paperi Ja Puu-Paper and Timber 79(4), 257-266.

Maloney, T., Paulapuro, H., and Stenius, P. (1998). "Hydration and swelling of pulp fibers measured with differential scanning calorimetry," Nordic Pulp \& Paper Research Journal 13(1), 31-36. DOI: 10.3183/npprj-1998-13-01-p031-036

Malu, S. P., Oko, O. J., Ugye, J. T., and Abah, J. (2013). "Characterization of Mbayion clay for its industrial potentials," Journal of Emerging Trends in Engineering and Applied Sciences 4(6), 769-772.

Malu, S. P., Ugye, J. T., and Donatus, R. B. (2018). "Characterization of clay for industrial application by physicochemical, XRF, and TGA methods," Trends in Science \& Technology Journal 3(1), 314-318. 
Nishiyama, Y., Kim, U. J., Kim, D. Y., Katsumata, K. S., May, R. P., and Langan, P. (2003). "Periodic disorder along ramie cellulose microfibrils," Biomacromolecules 4(4), 1013-1017. DOI: 10.1021/bm025772x

Nnuka, E. E., and Enejor, C. (2001). "Characterization of Nahuta clay for industrial and commercial applications," Nigerian Journal of Engineering and Materials 2(3), 9-12.

Nwajuagu, C. O., and Aneke, L. E. (2001). "Characterization of Ukpor clay deposits," Journal of Nigerian Society of Chemical Engineering 5(1), 1-3.

Nwankwojike, B. N., Onwuka, O. S., and Ndukwe, E. C. (2014). "An appraisal of different brands of portland cement in Umuahia industrial market, Nigeria," Journal of Research Information in Civil Engineering 11(2), 577-589

Nwoye, I. C. (2010). "Effect of water-steam transition temperature on the evaporation of water and shrinkage of clay during oven drying of clays," New York Science Journal 3(4), 33-38.

Ogunwusi, A. A. and Onwualu, A. P. (2013). "Impact of privatization of primary pulp and paper mills on performance of pulp and paper sector in Nigeria," Developing Country Studies 3(7), 109-119.

Perry, D. L. (2011). Handbook of Inorganic Compounds, CRC Press, Boca Raton, FL, USA.

Siva Prasad, G. V. S., Padmanabha Reddy, P., Swathi, M., Kiran Kumar, P. D. V., Praveenraja, T., and Naveen, M. (2015). "Study and behavior of some properties of papercrete brick with modular brick," International Journal of Engineering Research 3(3), 267-275.

Udohitinah, J. S., and Oluwadare, A. O. (2011). "Pulping properties of kraft pulp of kraft pulp of Nigerian-grown kenaf (Hibiscus cannabinus L.)," BioResources 6(1), 751761. DOI: 10.15376/biores.6.1.751-761

United States Environmental Protection Agency (USEPA) (1994). Characterization of Municipal Solid Waste in the United States: 1994 Update (Report No. EPA530-R-94042), Solid Waste and Emergency Response, United States Environmental Protection Agency, Washington, DC, USA.

Wang, S.-Y., Yang, T.-H., Lin, L.-T., Lin, C.-J., and Tsai, M.-J. (2007). "Properties of low-formaldehyde-emission particleboard made from recycled wood-waste chips sprayed with PMDI/PF resin,” Building and Environment 42(7), 2472-2479. DOI: 10.1016/j.buildenv.2006.06.009

Xing, C., Deng, J., Zhang, S. Y., Riedl, B., and Cloutier, A. (2006). "Properties of MDF from black spruce tops as affected by thermomechanical refining conditions," Holz als Roh- und Werkstoff 64(6), 507-512.

Zhou, Y., and Kamdem, D. P. (2002). "Effect of cement/wood ratio on the properties of cement-bonded particleboard using CCA-treated wood removed from service," Forest Products Journal 52(3), 73-81.

Article submitted: February 18, 2020; Peer review completed: May 16, 2020; Revised version received and accepted: May 31, 2020; Published: June 17, 2020.

DOI: 10.15376/biores.15.3.6033-6044 